\title{
THE DIRECTIONS OF INCREASING FINANCIAL STABILITY OF MUNICIPAL BUDGETS
}

\author{
Kizlargul TAJIBAEVA \\ Finance department, Tashkent institute of Finance, Uzbekistan
}

\section{ABSTRACT}

The research is devoted to study inter-budgetary relations in the case of Karakalpakstan. The question of providing stable municipal budget, the mechanisms of tax share, the problems of effectiveness and transparency in budget system are studied. The ways of solution of problems in inter-budgetary relations are suggested. The data analysis and statistical grouping are the main methods of research in this paper. The research is pioneer to study public finance problems in the case of Karakalpakistan where difficult social and ecological problems needed to be managed.

\section{JEL CLASSIFICATION \& KEYWORDS}

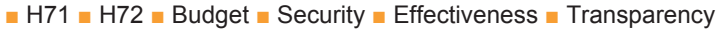

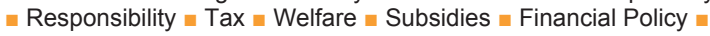

\section{INTRODUCTION}

Centralized government funds play a great role to implement social-economic and political policies in the country. Centralization gives opportunity to smooth the uneven income of different regions, and used to re-distribute of national income and flexible management of financial resources. As the main body to implement state financial policy the government identifies financial strategy for future periods, sets up practical actions and chooses the main instruments to reach the strategy. Market reforms and implementation of new economic and financial policy created new sub-financial systems in Uzbekistan.

The main sources of any financial system are formed by the revenues of corporations and income of individuals and as result all these summarize as balance of financial resources of the state. Mobilization and expenses of financial resources takes place during budget process.

\section{THE ANALYSIS OF THE REVENUES OF MUNICIPAL BUDGETS}

The recent idea's of global and regional development, social priorities and stability is dominating and getting popular in finance world. In state scale with complex territorial structure, it's impossible to reach stability and social orientation without forming necessary financial-economic bases well enough to provide independence for municipal budget management. Imperfection the structure of social sectors, ineffective use of resources are the main problems monitored in self-management of municipal government in Uzbekistan. The complex economic situation together with the lack of stable revenue bases of local budgets worsens self-management of municipal governments. The problems in relations between municipal and central government bodies adds more problems. At the same time new process of decentralization is continuing without full cover of finance for those new areas of responsibilities.

The valuation of real situation and potential opportunities of development tendencies of municipal structures plays important role to providing stable socio-economic development during the reforms of budget system of the Republic of Uzbekistan. To reach to the balanced budget is the key for stable socio-economic development of regions. Providing stability of budgetary system required for the solution to aforementioned problems. The academic research and practical recommendations on providing stability of municipal budgets in modern economy is priority

Table 1. The analysis of revenues structure of municipal budgets of the Republic of Karakalpakstan for 2007-2009

\begin{tabular}{|c|c|c|c|c|c|c|c|}
\hline \multirow[t]{2}{*}{ № } & \multirow[t]{2}{*}{$\begin{array}{l}\text { Revenue } \\
\text { sources }\end{array}$} & \multicolumn{2}{|l|}{2007} & \multicolumn{2}{|l|}{2009} & \multicolumn{2}{|c|}{$\begin{array}{l}\text { Changes from } \\
2007 \text { to } 2009\end{array}$} \\
\hline & & $\begin{array}{l}\text { Thousands } \\
\text { soum }\end{array}$ & $\%$ & \begin{tabular}{|l|} 
Thousa \\
nds soum
\end{tabular} & $\%$ & soum & $\%$ \\
\hline 1 & \begin{tabular}{|l|} 
Tax \\
revenues
\end{tabular} & 79122100 & 39.5 & $\begin{array}{l}192362 \\
860 \\
\end{array}$ & 49.2 & $\begin{array}{l}113240 \\
760 \\
\end{array}$ & \begin{tabular}{|l|}
9.7 \\
\end{tabular} \\
\hline 2 & VAT & 19003300 & 9.5 & 39864100 & 10.2 & 20860800 & \begin{tabular}{|l|l|}
0.7 \\
\end{tabular} \\
\hline 3 & Profit tax & 4591800 & 2.3 & 11714600 & 2.9 & 7122800 & \begin{tabular}{|l|}
0.6 \\
\end{tabular} \\
\hline 4 & \begin{tabular}{|l|}
$\begin{array}{l}\text { Corporate } \\
\text { property } \\
\text { tax }\end{array}$ \\
\end{tabular} & 4879000 & 2.4 & 7072200 & 1.8 & 2193200 & 0.4 \\
\hline 5 & \begin{tabular}{|l} 
Property \\
tax from \\
individuals
\end{tabular} & 240900 & 0.1 & 1252400 & 0.3 & 1011500 & 0.2 \\
\hline 6 & Income tax & 24437400 & 12.1 & 60434200 & 15.6 & 35996800 & 3.5 \\
\hline 7 & $\begin{array}{l}\text { Municipal } \\
\text { taxes }\end{array}$ & 2916500 & 1.4 & 8164700 & 2.1 & 5248200 & \begin{tabular}{|l|}
0.7 \\
\end{tabular} \\
\hline 8 & Customs & 784800 & 0.4 & 1811200 & 0.4 & 1026400 & 0 \\
\hline 9 & \begin{tabular}{|l|} 
Other \\
taxes and \\
non-tax \\
revenues \\
\end{tabular} & 487400 & 0.2 & 990600 & 0.2 & 503200 & 0 \\
\hline 10 & $\begin{array}{l}\text { Water } \\
\text { taxes }\end{array}$ & 1500500 & 0.7 & 2705300 & 0.6 & 1204800 & 0.1 \\
\hline 11 & $\begin{array}{l}\text { Tax for } \\
\text { small } \\
\text { enterprises }\end{array}$ & 2821200 & 1.4 & 11061100 & 2.8 & 8240900 & 1.4 \\
\hline 12 & $\begin{array}{l}\text { Infrastruct } \\
\text { ure tax }\end{array}$ & 1031700 & 0.5 & 4996510 & 1.3 & 3964810 & 0.8 \\
\hline 13 & $\begin{array}{l}\text { Entreprene } \\
\text { urship } \\
\text { taxes }\end{array}$ & 1475900 & 0.7 & 3091300 & 0.8 & 1615400 & \begin{tabular}{|l|}
0.1 \\
\end{tabular} \\
\hline 14 & Excise tax & 6332700 & 3.1 & 7955950 & 2 & 1623250 & \begin{tabular}{|l|}
-1.1 \\
\end{tabular} \\
\hline 15 & Land tax & 6254000 & 3.2 & 31247700 & 7.9 & 24993700 & 4.7 \\
\hline 16 & $\begin{array}{l}\text { Other non- } \\
\text { tax } \\
\text { transfers }\end{array}$ & 121341155 & 60.5 & $\begin{array}{l}198557 \\
365\end{array}$ & 50.8 & 77216210 & \begin{tabular}{|l|}
-9.7 \\
\end{tabular} \\
\hline 17 & $\begin{array}{l}\text { Subventi } \\
\text { ons }\end{array}$ & 68074012 & 33.9 & $\begin{array}{l}129303 \\
283 \\
\end{array}$ & 33.1 & 61229271 & \begin{tabular}{|l|}
-0.8 \\
\end{tabular} \\
\hline 18 & $\begin{array}{l}\text { Revenues } \\
\text { given to } \\
\text { municipal } \\
\text { budgets } \\
\text { from } \\
\text { central } \\
\text { budget }\end{array}$ & 53267143 & 26.6 & 69254082 & 17.7 & 15986939 & -8.9 \\
\hline & $\begin{array}{l}\text { Summary } \\
\text { of } \\
\text { revenues }\end{array}$ & 200463255 & 100 & $\begin{array}{l}390920 \\
225\end{array}$ & 100 & $\begin{array}{l}190456 \\
970\end{array}$ & \\
\hline
\end{tabular}

Source: Calculated by the author according to the information of Ministry of Finance of the Republic of Karakalpakstan. 
Printed from: Serif PagePlus 14,0,5,27 Copyright (@ 1994-2009 Serif (Europe) Ltd. All Rights Reserved

Printed on: 28.3.2011 18:39:46

Publication name: Journals.cz_EJBE_Vol2.ppp, Page: 10

VOLUME 2, 2011

task in research area. Tables of 1 and 2 study the revenues and expenditures of the municipal budgets of the Republic of Karakalpakstan as an example.

Almost $50 \%$ of revenues of municipal budgets contents from income tax, land tax and VAT, the analysis in table 1 shows. The analysis of the period of 2007-2009 shows:

1. Tax revenues are increasing. For example, income tax increased from $12,1 \%$ to $15,6 \%$.

2. The increase of revenue from land tax to $4,7 \%$ contributed to revenues of budget of the Republic of Karakalpakstan.

The main directions of expenditures of municipal budgets. The municipal sources (taxes and non-tax revenues) of budgets are insufficient for financing municipal expenditures. Even though there are some financial support from the budget of the republic it's not enough to provide full finance.

The tax revenues are the main source of municipal budgets and where production sector of economy are the main factor to provide the financial independence to regions. The increase of healthcare expenditure from $2007(17,4 \%)$ to 2009 was only $0,2 \%$ the analysis of practical data showed in table 2.

Expenditures to education with $42,2 \%$ is the highest proportion in municipal expenditures for 2009 in the Republic of Karakalpakstan. Comparing to 2007 it was reduction for $1 \%$. The high proportion is explained with the given priority to education in Uzbekistan.

\begin{tabular}{|c|c|c|c|c|c|c|c|}
\hline \multirow[t]{2}{*}{ № } & \multirow[t]{2}{*}{$\begin{array}{l}\text { Expenditu } \\
\text { res }\end{array}$} & \multicolumn{2}{|l|}{2007} & \multicolumn{2}{|l|}{2009} & \multicolumn{2}{|c|}{$\begin{array}{l}\text { Change } 2007 \text { to } \\
2009\end{array}$} \\
\hline & & \begin{tabular}{|l|} 
Thousands \\
soum
\end{tabular} & $\%$ & $\begin{array}{l}\begin{array}{l}\text { Thousands } \\
\text { soum }\end{array} \\
\end{array}$ & $\%$ & soum & $\%$ \\
\hline 1 & $\begin{array}{l}\text { Agriculture } \\
\text { and irrigation } \\
\text { systems }\end{array}$ & 1960724 & 0.9 & 2227538 & 0.6 & 266814 & 0.3 \\
\hline 2 & Transport & 163570 & 0.08 & 333924 & 0.08 & 170354 & 0 \\
\hline 3 & $\begin{array}{l}\text { Providing } \\
\text { general } \\
\text { property } \\
\text { services }\end{array}$ & 773997 & 0.4 & 924834 & 0.02 & 150837 & - \\
\hline 4 & $\begin{array}{l}\text { Social } \\
\text { expenditures }\end{array}$ & 2750688 & 1.3 & 4476081 & 1.4 & 1725393 & $\overline{-} .2$ \\
\hline 5 & $\begin{array}{l}\text { Foreign } \\
\text { economic } \\
\text { activity } \\
\text { expenditures }\end{array}$ & 0 & 0 & 1744314 & 0.4 & 1744314 & 0.4 \\
\hline 6 & Education & 82530483 & 41.2 & 164652698 & 42.2 & 82122215 & 1 \\
\hline 7 & $\begin{array}{l}\text { Culture and } \\
\text { mass-media }\end{array}$ & 1707125 & 0.8 & 3149188 & 0.8 & 1442063 & 0 \\
\hline 8 & Science & 81485 & 0.04 & 187248 & 0.04 & 105763 & 0 \\
\hline 9 & Healthcare & 34867563 & 17.4 & 68822852 & 17.6 & 33955289 & 0.2 \\
\hline 10 & Sport & 10365 & 0.005 & 62927 & 0.01 & 52562 & $\begin{array}{l}0.0 \\
05\end{array}$ \\
\hline 11 & $\begin{array}{l}\text { Training and } \\
\text { re-training of } \\
\text { specialists }\end{array}$ & 21013801 & 10.5 & 47690575 & 12.2 & 26676774 & 1.7 \\
\hline 12 & $\begin{array}{l}\text { Social } \\
\text { service } \\
\text { sector }\end{array}$ & 965081 & 0.5 & 2102852 & 0.5 & 1137771 & 0 \\
\hline 13 & $\begin{array}{l}\text { Central } \\
\text { government }\end{array}$ & 378750 & 0.2 & 6294059 & 1.6 & 5916209 & 1.4 \\
\hline 14 & \begin{tabular}{|l|} 
Municipal \\
government
\end{tabular} & 2030936 & 1 & 4425356 & 1.1 & 2394420 & 0.1 \\
\hline 15 & $\begin{array}{l}\text { Reserve } \\
\text { funds }\end{array}$ & 478183 & 0.2 & 786628 & 0.2 & 308445 & 0 \\
\hline \multirow[t]{2}{*}{16} & $\begin{array}{l}\text { Other } \\
\text { expenditure }\end{array}$ & 50750504 & 25.3 & 83039151 & 21.5 & 32288647 & 3.8 \\
\hline & $\begin{array}{l}\text { Summary of } \\
\text { expenditures }\end{array}$ & 200463255 & 100 & 390920225 & 100 & $\begin{array}{l}190456 \\
970\end{array}$ & \\
\hline
\end{tabular}

Source: Calculated by the author according to the information of Ministry of Finance of the Republic of Karakalpakstan.
The other expenditures are about $20 \%$ in total. This explains non-transparency mechanisms which may lead to instable budget processes.

The main part of municipal expenditures directed to social tasks and events which consequently will benefit for local citizens.

The reforms on regional level aims to construction of effective self-management system with the stable municipal budgets and increased legal independence of local government.

\section{RECOMMENDATIONS ON INCREASING FINANCIAL} STABILITY OF MUNICIPAL BUDGETS

Inter-budgetary relations are the main object of control of financial security in the Republic of Uzbekistan in budget processes. There is no question that effective regulation of inter-budgetary relations are the key element in providing financial security. And these requires:

1. The mechanisms of inter-budgetary relations are elaborated and implemented:

- Eliminating to present invalid privileges and economically not justified expenditure opportunities to any level of government should be eliminated. The mechanisms of providing responsibility and accountability of financial duties needed to be increased;

- Exception of providing additional resources to balance regional budgets;

- All expenditures must have it's own sources of finance (taxes) according to the level of different budgets :

- Control of usage of budget money from central government should be increased together with financial aid to the regions;

- The transparency of inter-budgetary relations must be provided

2. The measure of effective budgeting (can be used the equivalency of revenues and expenditures, or the results of budget investments or other measures) and the finite ways of providing stable municipal budgets should be determined;

3. The budget flows and rhythms needed to be optimized (to minimize directions of budget flows on the way to budget transfer receivers).

The full trust between central and regional government is the key to provide financial security of the country. Financial relations needed to be constructed on the principles of legality, effectiveness, transparency (or open to the public), responsibility and on real agreement for all solutions of problems to the interest of regions (to decrease tax bases and etc.).

\section{CONCLUSION}

In conclusion we note that in this research we studied some of many problems related to financial security of Uzbekistan. The goal is to present the urgency of the problem and to give some solutions of these problems. We want to note that all these questions needed to be scientifically researched.

\section{REFERENCES}

1. "About Budget System" Law of the Republic of Uzbekistan. December 14,2000

2. "About legislation basis of company activities". August 29 , 1998;

3. "About Treasury execution of State budget". Law of the Republic of Uzbekistan. August 26, 2004;

4. "About Informatisation". Law of the Republic of Uzbekistan. December 15.2002. 